\title{
A Review on Requisite Generic Attributes for Engineering Graduates
}

\author{
S. Meenakshi \\ Department of \\ Humanities \& Social Sciences \\ National Institute of Technology \\ Rourkela, Odisha, India \\ e-mail: mee kshi@rediffmail.com
}

\author{
Amiya Kumar Rath \\ Department of \\ Computer Science \& Engineering \\ VSSUT, Burla, Odisha, India \\ e-mail: amiyaamiya@,rediffmail.com
}

\author{
Seemita Mohanty \\ Department of \\ Humanities \& Social Sciences \\ National Institute of Technology \\ Rourkela, Odisha, India \\ e-mail: seemita@nitrkl.ac.in
}

\begin{abstract}
Engineering education today has seen enormous growth and development in terms of the quality of education and the deliverables. The profession is experiencing major changes in knowledge, equipment, systems and management in order to achieve higher standards in a competitive world. Consequently, engineering firms continuously need engineers with strong technical knowledge, in addition to being well-equipped with employability skills. In order to face new challenges, new opportunities and ever challenging circumstances, new engineers have to continually adapt and upgrade necessary skills such as self-learning, problem solving and other personal skills that can be applied in different situations. Apart from the technical knowhow's and show-how's, they also need the requisite interpersonal skills to thrive in the field in the long term. In this paper, we review the package of skill set anticipated from an engineering graduate from the employer's perception, and reveal the existing competency gaps for successful execution of engineering services.
\end{abstract}

Keywords - Engineering, Employability, Competencies, Skill, Generic Attributes, Graduate Attributes

\footnotetext{
Seemita Mohanty

Department of

Humanities \& Social Sciences

National Institute of Technology

Rourkela, Odisha, India

e-mail:seemita@nitrkl.ac.in
}

\section{Introduction}

Engineering is an activity that is indispensable to meeting the needs of people; for economic growth and for provision of services to society. It is pervasive, woven through the fabric of our everyday lives. It plays a pivotal role in creating not just our smart phones but also the network that keeps us connected and the music and applications that we download. Engineering is built into the lighting and heating in our homes, and the grid and the power stations that keep them working. Engineering creates not just our vehicles but also the bridges, tunnels and roads that facilitate our vehicles to move us where we desire to go and engineering is inbuilt into our most extraordinary feats, enabling us to travel faster and explore further to the depths of the ocean and into space.

The National Academy of Engineering (NAE) report clearly pictures that, "The forthcoming year 2020 will be ruled by technological innovations embedded with multidisciplinary; cultural, political, social and economical forces. To cope up with the impending years an engineer graduate requires to possess strong analytical skills, cleverness, creativity, communication skills, followed by working knowledge of both business and management, leadership, high moral standards, professionalism, new ideas, flexibility, agility, resilience and lifelong learning".

In view of the stance taken by the NAE report regarding engineering graduates, it is crucial to take 
into account the employers' satisfaction on vital skills as component of the graduates' preparation to enter into the world of work. Therefore, the objective of engineering education is to shape the graduates to comply with the industry requirements. The students must be prepared to work with latest technology, concurrently with an entrepreneurial and innovative bent of mind. Therefore to build up the skills required for high-end engineering careers, we must make sure that the engineering program is actually developing these characteristics within the students.

\section{A. Outline}

The paper is organized as follows: Section II carries background information on generic attributes. Section III holds the definition part, Section IV provides the purpose of study, Section V contains the information on gaps existing among engineering graduates and Section VI deals with the skills that employers expect from the engineering graduates, followed by Section VII contains detailed analysis from the review findings, Section VIII provides a clear picture of the Accreditation board and the learning outcomes and lastly, Section IX provides the conclusion to the review paper.

\section{Precursor}

Simon Barrie [1] states that the roots and facts of the generic attributes are in the archives of 1828 and 1862 of British universities and the University of Sydney. Since 1980s, employability skills has started to gain popularity in the world. The necessity of possessing generic skills by engineers has possibly amplified in recent years, even though the term 'generic' has been a buzzword of the belated 1990's, and such skills were alive in various educational programmes prior to the 1980's. Several programmes integrated diverse subject areas to assist in the enhancement of generic skills; however, these skills differed from discipline to discipline.

\section{Generic Attributes}

The multitude of terminologies that are used for these skills include such terms as, generic skills, generic attributes, graduate attributes, employability skills, graduate capabilities, core skills, key skills, and so on. Generic abilities are defined as traits, features or behaviours that are not explicitly the part of the profession but required for success in the profession. But it is usually seen that there are certain discrepancies regarding the description of generic skills, from the perspective of different stakeholders. Generic skills are widely denoted as an array of virtues and abilities, and viewed progressively as vital in higher education. It comprises of basic skills which include logical and analytical reasoning, problem solving, creativity and intellectual curiosity followed by other skills such as oral and written communication skills, working with teams, ability to access information and manage knowledge, personal characteristics such as moral values, ethical practices, determination, honesty, open-mindedness and patience. These varied compilation of characteristics and abilities are different from the discipline-definite knowledge and related technical skills that are associated with higher education.

\section{A. Definition: Different Views}

The term graduate does not refer to a qualification of a certain type, rather it clearly states about level of the qualification acquired at the time of exit. Graduate attributes consist of independently quantifiable outcomes that are the indicators of a graduate's potential to obtain the ability to exercise at the correct level. Graduate attributes are the standard attributes projected from a graduate by an accredited programme [2]. Numerous studies have provided detailed breakdowns and taxonomies of particular skills and attributes required to promote among engineering graduates as a learning outcomes.

Several substitutable expressions linked to generic skills as convertible skills and key competency skill were highlighted in [3]. Freeman et al. [4] refer these as soft skills, and Barrie [5] has defined that the generic skills can be conceptualized as both output and progressions supporting curriculum, design and classroom teaching and learning. As mentioned above generic attributes are known by several names; however industry's preferred term is employability skills [6]. Barrie [7] uses the term generic graduate attributes while Curtis \& McKenzie [8] refer to them as employability skills. Both Bowden et al., [9] and [10] term generic attributes as professional skills and personal transferable skills respectively.

Soft skills or generic skills are behavioral skills characterized by intangible attributes and entail emotional intelligence; and by their very subjective nature are quite hard to measure, and rather relational in nature. In fact, some have referred to these generic skills as a set of achievements, understandings, and 
personal attributes that enable prospective graduates more likely to gain employment and be successful in their chosen field or career.

\section{Importance Of Generic Attributes}

In general, engineering students belong to diverse disciplines and they come from different background and culture. To face the challenges of today's corporate world, the students must possess certain generic skills, otherwise known as employability skills. Employability skills are very essential in the current global job market. These skills give striking advantage to a candidate during a job interview. Even for a technology-centric occupation like engineering, soft skills are also very important for engineers to apply their technical knowledge at work effectively. Employers are now emphasizing that success as an engineer requires more than simply strong technical capabilities. Also needed are skills in communication and persuasion, the ability to lead and work effectively as a team member, and an understanding of the non-technical forces that affect engineering decisions. Consequently, engineering educators today are confronted with the issue of how best to ensure that engineering graduates will continue to be relevant and bring value to the job market.

Bodmer et al. [11] stated that "The challenge of engineering education is to simultaneously prepare students for their first job and their career 25 years later." This perspective recommends that engineering education must deliver preliminary competencies for engineering work and developmental competencies for careers.

The primary obstacle of India's economic growth resulting from insufficient supply of skilled employees was articulated in [12]. Over the past 5 years, Indian economy grew more than 8 percent on an average that included the deficient financial crisis of 2009. However skill deficiency is one of the foremost limitations for a majority of the Indian industries.

\section{A. Global Context}

Bath et al., [13] insist that graduate skills must be embedded into the curriculum. Some authors concur the purpose of graduate skills as mainly for selfregulated learning and reflective learning [14] [15][20].The paper [16] points out that in employers' perspective, employability is the bonus value added to the array of skills offered by a job aspirant. Authors in
[17] note that the graduate attributes are indivisible elements that address disciplinary knowledge, values and attitudes as well as skills for lifelong learning of an graduate. The paper [18] emphasized that employability can be thought of as capability of being hired whereby, Candy [19] suggests that graduate skills can motivate and enhance students' devotion towards life-long learning.

\section{B. Indian Context}

From an Indian perspective, the study [21] observes that skill deficiency remains one of the major constraints for continuous growth of the Indian economy. The writers find that employers perceive basic employability skills and communication skills as vital. It has been found that the skill gaps are truly serious in the higher ordering thinking skills, ranked according to Bloom's Taxonomy. The study conducted in Indian context highlights that the demands of employers towards the skills vary across economic sectors, company size and region. It has been suggested that an engineering education institution ought to 1) look for improvising the skills of engineering graduates 2) identify the significance of soft skills 3) focus attention towards the appraisal, teaching-learning procedure and syllabus away from low order-thinking skills, such as remembering, understanding and applying, and instead target towards higher order thinking skills, such as analyzing and evaluating the engineering problems followed by creative thinking and innovation.

Ministry of Human Resources \& Development [22] study reveals that the increase in the number of students enrolled in the engineering education system is in response to the greater demand for engineers. In the period of 1998 to 2008 , the number of students joining engineering studies increased eight hundred percent. This quantitative growth is extensively perceived to have led to an average drop in the teaching learning process, quality of the students entering into the engineering system, and subsequently, the quality of the engineering graduates.

A National Association of Software and Services Companies \& McKinsey [23] report describes that employers of IT/ITES related multinational companies admit that due to the lack of requisite skill set among fresh graduates, only 25 percent of the engineering graduates are employable in these companies. This clearly indicates the shortcomings in the engineering education system. 
Research has continuously identified that appropriate graduate skills are effectually developed in the framework of knowledge, rooted within curriculum. Today, researchers have altered the direction of research, passing beyond curriculum mapping and embedding. They debate on how the skills of graduates are attained and progressed, and how effectively instructors can raise and increase the quality and value of generic skills amongst the students through appropriate use of teaching and learning strategies.

\section{Generic Attribute Gaps Existing Among Engineering Graduates From Varied Perceptions}

Multiple studies have identified that gaps of generic competencies exist between engineering education and the skills required for carrying out engineering works.

The most recent review in study [24] noted "Industrial training is considered to be an effective tool to enhance graduates' employability." The authors conducted a survey among 179 employers across Malaysia. The employers suggested that students need to improve their behavioral and technical skills.

The survey conducted in paper [25] results the dissatisfaction levels found from engineering graduates by Indian employers. It clearly states that $33 \%$ graduates lack in problem solving skills followed by mathematics, science and technical skills. The survey concludes by reporting that the Indian engineering graduates are poor in communication and teamwork. The government of India conducted an employer satisfaction survey during the year [21] and emphasized that engineering students were not being trained adequately on core design skills such as problem solving skills and creativity. Similarly, teamwork skills of engineering graduates occupied the highest rating among the employers by Spinks et al. [26].

The Henley Report for the Royal Academy of Engineering [27] concludes that the future roles of engineering graduates range from a technical specialist to the engineer as a Trans- disciplinary integrator or to engineers in the role of creative change agents who shape the future of engineering industry. This poses the question of whether to equip students with a broad knowledge base in many domains, or prepare them for specific job tasks and subsequent contribution in a narrow subject area (technical depth).

Various researchers have studied about how variation in the professional underlying structure has influenced demands of engineering education and engineers. It includes the changes as a relationship of in-house engineering work to consultancy; globalization; speedy technological transformation; expansion of technical area of activities; and increased concern related to the issues of environment [28]- [31].

More recently, gaps in leadership, social skills \& communication were highlighted in the SPINE study made by [11]. Many reviews and surveys of engineering education have ascertained the prime competency gaps exists in similar areas [32]-[35] . Scott and Yates [37] identified a large gap of competency known as Emotional Intelligence. These literature clearly indicate the consistent gaps associated with engineering education.

\section{What Does Industry Expect From Engineering Graduates?}

Jolly.S.S [36] reported that due to the globalised nature of place of work, barely $25 \%$ of the Indian engineering graduates are employable. The author stressed that the area of skill set where Indian engineering graduates need to improve are language skills, working with teams, adapting the latest technology, leadership skills and desire to learn new subjects related to the field of work.

The survey conducted in Kelang industrial area in Malaysia found that the most rated skill is communication skill [38]. According to Rao [39] generic skills build self-esteem and self-confidence at the personal front that enable personal and professional advancement, and at the same time create opportunities at the professional front. In this connection, not only hard skills are necessary, but also soft skills or generic skills are also equally indispensable to ensure employability of university graduates. Hard skills are technical or administrative procedures that relate to an organization's core business.

Lock [40] concluded the findings of studies conducted by Harvey [41] by having three main 
selection factors for placements. i.e. team working, communication skills and learning skills. Competencies related to technical theory received low rating in the survey conducted by [42]. Problem solving features in accreditation outcomes was one of the highlights in study [44].

Practical knowledge rated the most significant skill by Spinks et al. [26] study. In the same study theoretical understanding was rated to be of comparatively less significant among skills needed by engineering graduates that employers hoped to employ within the next 10 years period.

Many researchers, and survey results in the most recent decade have indicated that the employers are most dissatisfied with engineering graduates' practical application of theory, and business skills [26] [35].

The National Academy of Engineering, USA [31] identified a progressing need for robust analytical skills, and practical ingenuity. Lee Fui Tong's [44] study reveals that employers seek for aspects such as interpersonal communication, planning or scheduling, people management, problem solving, team management and cost controlling. According to Harvey et al [41] most employers look for graduates who are proactive, can use higher-level skills including 'analysis, critique, synthesis and multi layered communication to facilitate innovative teamwork in catalyzing the transformation of their organization'.

\section{Analysis From The Review Findings}

This section presents a more detailed description of the expected generic attributes from an employer's perspective. The outcome comprises a variety of papers' focus on the expectations of employers. The results contain varied attributes expected by an industry within the span of $2002-2013$. The absolute sets of expected graduate attributes identified during the review are listed in Table I. Table I also shows the division of papers included in this literature review within the timeline of 12 years and each timeline spans four years.

The findings given in the Table II clearly shows that teamwork and communication skill occupy the position of most necessary attributes. Ccreativity or innovation comes next, followed by problem solving skills and learning skills. These are the important skills that an engineering graduate is expected to possess for getting a job.

Table 1

Vital Generic Attributes Identified In The Review Of Literature

\begin{tabular}{|c|l|}
\hline Timeline & \multicolumn{1}{|c|}{ Generic attributes ( GA) } \\
\hline $2010-2013$ (Phase -3) & $\begin{array}{l}\text { Behavioural skills, Technical skills, } \\
\text { Communication Skill, Leadership, } \\
\text { Teamwork. }\end{array}$ \\
\hline $2006-2009$ (Phase -2) & $\begin{array}{l}\text { Teamwork, Communication Skill, } \\
\text { Lifelong Learning skills, Practical } \\
\text { knowledge, Problem Solving, } \\
\text { Creativity. }\end{array}$ \\
\hline $2002-2005$ (Phase - 1) & $\begin{array}{l}\text { Problem Solving, Communication } \\
\text { Emotional Intelligence, Creativity, } \\
\text { Business skills, Analytical skills, } \\
\text { Leadership. }\end{array}$ \\
\hline
\end{tabular}

Table 2

During The Timeline From 2002 - 2013

The Review Gives A Picture of

An Employer's Expectations From An Engineering Student As Listed Below

\begin{tabular}{|l|l|}
\hline Expected Generic Attributes & Occurrences \\
\hline Teamwork & 6 \\
\hline Communication Skill & 6 \\
\hline Creativity / Ingenuity & 4 \\
\hline Problem Solving Skills & 3 \\
\hline Leadership & 2 \\
\hline Practical Knowledge & 1 \\
\hline Business Skills & 1 \\
\hline Social Skills & 1 \\
\hline Lifelong Learning & 3 \\
\hline Analytical Skills & 1 \\
\hline Technical Skills & 1 \\
\hline Emotional Intelligence & 1 \\
\hline Behavioral Skills & 1 \\
\hline
\end{tabular}


A. Analysis on the expected outcomes or generic attributes

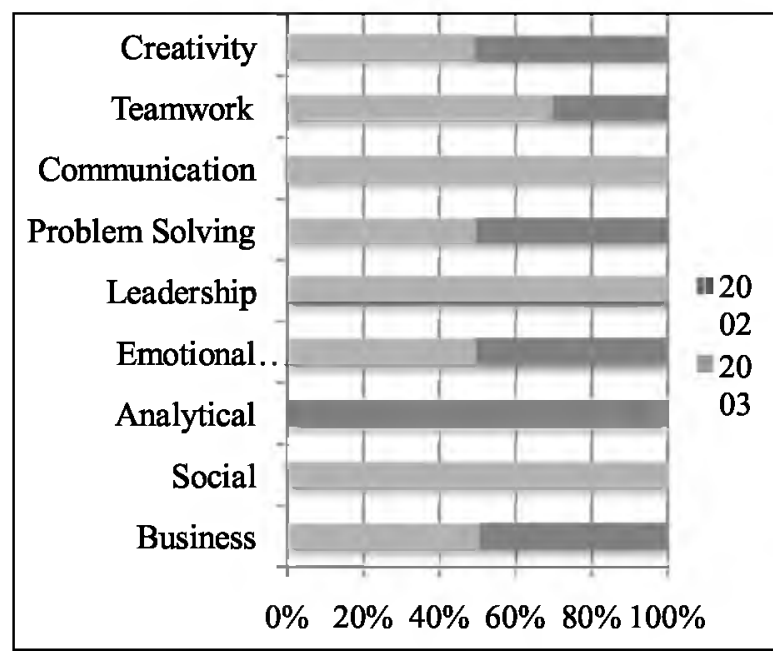

Fig. 1 Expected Generic Attributes during Phase-1

It can be determined from Fig.1 that creativity, teamwork, communication, problem solving, leadership, emotional It can be determined from Fig.1 that creativity, teamwork, communication, problem solving, leadership, emotional intelligence, analytical, social and business skills were the expected engineering graduate attributes during Phase -1 .

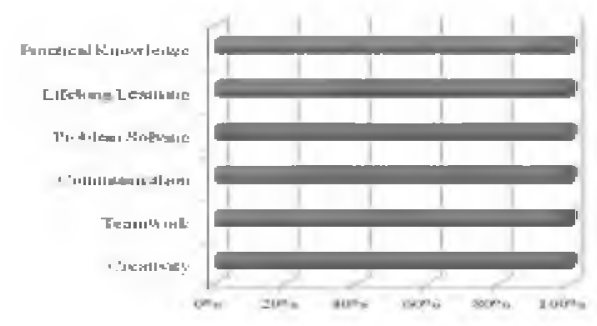

Fig. 2 Expected Generic Attributes during Phase-2

The Phase-2 attributes have been shown in Fig.2. Practical knowledge, lifelong learning, problem solving, communication, teamwork and creativity skill sets have been emphasized by various industries.

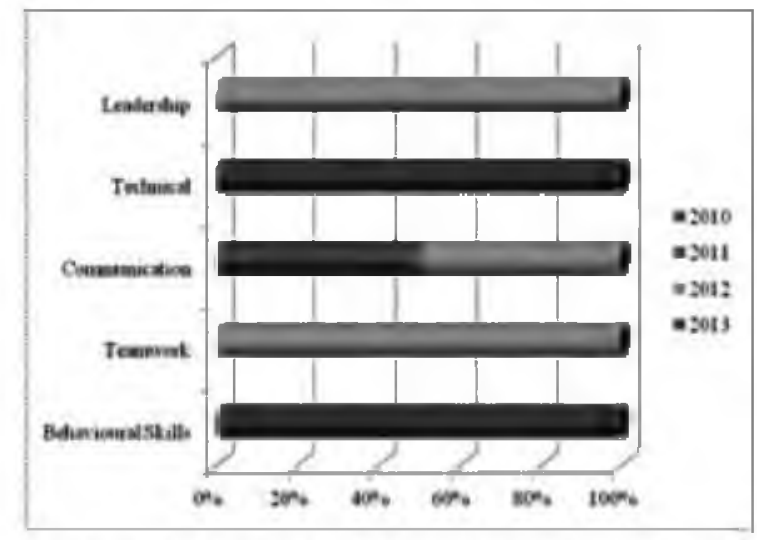

Fig. 2 Expected Generic Attributes during Phase-2
As shown in Fig.3, leadership, technical skills, communication, teamwork and behavioral attributes have taken added importance during phase-3.

By observing the charts plotted in Fig 4 it is evident that for an engineer to work effectively, teamwork, communication, problem solving, lifelong learning and creativity skills are very important. The results clearly highlight that employers are now emphasizing that success as

an engineer requires more than simply strong technical capabilities.

\section{A. Role of Accreditation Boards}

Responding to the needs of industries, leading engineering educational governing bodies in Australia, Europe, New Zealand, USA, Malaysia, Japan have carried out review of the engineering education outcomes which include the generic skills elements ( Engineers Australia, 2005; European Network for Accreditation of Engineering Education, 2008; Institution of Professional Engineers, New Zealand, 2009; Accreditation Board for Engineering and Technology (ABET), 2012; International Engineering Alliance (IEA), 2009; Quality Assurance for Higher Education, 2010; Maillardet, 2004; Engineering Council, 2009) [48].

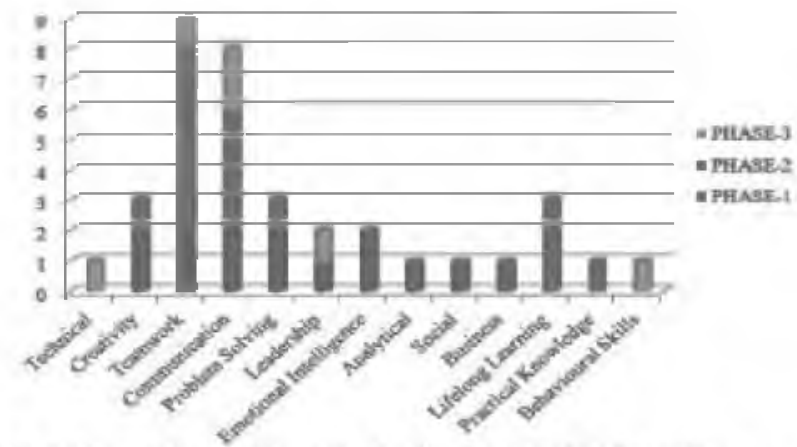

Fig. 4 Comparison of Generic Attributes of all the Three Phases

The influence of accreditation based upon learning outcomes of student was introduced by the accreditation board of engineering and technology (ABET) in the mid-1990s [25]. ABET is the worldwide leader in the accreditation of engineering programs. It currently has 32 members which work together to review and accredit degree programs in the United States and in the international arena.

This means that degree programmes are accredited on the skills and knowledge graduates have when leaving the university rather than on how many hours 
of teaching time is dedicated to each particular subject [45].

The Indian higher education system occupies the third biggest system in the world. For past two decades, India has evidenced extraordinary growth and development in technical education. There are two central bodies engaged in institution accreditation. The National Accreditation Assessment Council (NAAC) established in 1994 by the University Grants Commission to construct quality as a vital element blended with both the internal and external quality assessment and accreditation [49]. The National Board of Accreditation (NBA) [48] was formed to measure the qualitative competence of educational institutions from diploma level to post-graduate level in engineering and technology, architecture, pharmacy, management and related disciplines. As an autonomous body it came into existence in the year 2010.

\section{Graduate attributes proposed by various accreditation boards}

The Accreditation Board for Engineering \& Technology (ABET) [48] criteria include eleven engineering graduate program outcomes. The outcomes comprise of both generic engineering aspects and generic engineering items. Engineering graduate must have the following abilities:

- Knowledge of Science, Engineering and Mathematics

- To perform experiments by designing, conducting as well an ability to analyze and interpret the result.

- Design a process to meet the needs of restraints such as social, economic, ethical, environmental, production, sustainability, political and health and safety issues.

- Recognize, formulate and find solutions for engineering problems

- Work on multidisciplinary groups

- Professional and ethical responsibility

- Effective communication

- Understand the impact of engineering solutions in a global economic, environmental, and social context;

- Life-long learning

- Familiarity of current issues; and

- Use these techniques, skills and modern engineering tools necessary for engineering practice.

National Board of Accreditation (NBA), the India accreditation criteria state that the engineering students of accredited programs must develop 12 stipulated generic Graduate Attributes. NBA's engineering program outcomes, that is, the anticipated learning outcomes for graduates are based upon the internationally agreed category of skills and knowledge that graduates are required to possess at the time of graduation [46].

National Board of Accreditation outlines the following GA parameters for UG Engineering:

- Engineering knowledge

- Problem analysis

- Design/development of solutions

- Conduct investigations of complex problems

- Modern tool usage

- The engineer \& society

- Environment \& sustainability

- Ethics

- Individual and team work

- Communication

- Project management \& finance

- Lifelong learning

\section{Conclusion}

Today's technology and economy have provided extensive attention to generic skills. Worldwide, current debates and discussions focus on the role played by generic skills for being an effective engineer, and about the aim of higher education, and how well education can develop a person who can be employable and competent to make a contribution to the society.

In today's changing global environment, many organizations have voiced the need for stronger softskills for engineering graduates. Therefore, generic skills should be trained as an integral part of the learning activities of students and be assessed as part of the overall assessment of subject content. It is crucial to take into account employers' needs and expectations on necessary skills as a vital component of graduates' preparation to enter the world of work. 


\section{References}

[1] Simon Barrie, "Rethinking Generic Graduate Attributes", Quality Assurance in Education, vol.27, pp.19-27, 2005.

[2] http://www.ieagreements.org/GradProfiles.cfm

[3] L.Treleaven and R.Voola, "Integrating the development of graduate attributes through constructive alignment", Journal of marketing education, vol.30, pp. 160-173, 2008.

[4] M.Freeman, P.Hancock, L.Simpson, C.Sykes, P.Petocz, I.Densten, and K.Gibson, "Business as usual. ABDC Scoping Report", Sydney: Australian Business Deans Council.

[5] S. C. Barrie, "A conceptual framework for the teaching and learning of generic graduate attributes", Studies in higher education, vol.32, pp.439-458, 2007.

[6] Allen Consulting Group, Assessment and reporting of employability skills in training packages, Department of Education, Science Training, Melbourne, 2006.

[7] S. C. Barrie, "A research $\square$ based approach to generic graduate attributes policy", Higher Education Research and Development, vol.23, pp.261-275, 2004.

[8] D.Curtis and P.McKenzie, "Employability skills for Australian industry: Literature review and framework development", Australian Council for Educational Research, 2001.

9] J.Bowden, G.Hart, B.King, K.Trigwell, and O.Watts, "Generic capabilities of ATN university graduates", Canberra: Australian Government Department of Education, Training and Youth Affairs, 2000.

[10]I. Drummond, I. Nixon, and J.Wiltshire, "Personal transferable skills in higher education: the problems of implementing good practice", Quality assurance in education, vol.6, pp.19-27, 1998.

[11]C.Bodmer, A.Leu, L.Mira, and H.Rütter, "Successful Practices in International Engineering Education", SPINE final report, 2002.

[12]web.worldbank.org > Data \& Research > Research , WDRs

[13]D.Bath, C.Smith, S.Stein, and R.Swann,"Beyond mapping and embedding graduate attributes: bringing together quality assurance and action learning to create a validated and living curriculum", Higher Education Research \&

\section{Development, vol.23,pp.313-328,2004}

[14]M.Boekaerts, "Self-regulated learning: A new concept embraced by researchers, policy makers, educators, teachers, and students", Learning and instruction, vol.7,pp.161-186, 1997.

[15]J.Luca, R.Oliver, "A framework to promote learning and generic skills", Proceedings of World Conference on Educational Multimedia, Hypermedia and Telecommunications 2003, 2003.

[16]M.Patrickson, R.Ranzijn, "Employability of older workers", Equal opportunities international, vol.22, November 2003.

[17]G.Hoban, G.Lefoe, B.James, S.Curtis, M.Kaidonis, M.Hadi, M. Lipu, C.Mcharg, and Collins, "A web environment linking university teaching strategies with graduate attributes",2004.

[18]R.Waterman, J.Waterman, B.Collard, "Toward a career-resilient workforce", Harvard business review, pp-87-95, 1994.

[19]P. C. Candy, "Self-Direction for Lifelong Learning", A Comprehensive Guide to Theory and Practice, 1991.

[20]M.Boekaerts and E.Cascallar, "How far have we moved towards the integration of theory and practice in self-regulation? Educational Psychology Review", pp.199-210, 2006.

[21]Blom, Andreas and Hiroshi Saeki,"Employability and Skill Set of Newly Graduated Engineers in India", Policy Research Working Paper No. 5640, The World Bank South Asia Region Education Team, 2011.

[22]MHRD, Ministry of Human Resource Development, Annual Report, New Delhi, India, 2009.

[23]NASSCOM \& McKinsey Report, "Extending India's Leadership of the Global IT and BPO Industries", New Delhi, India, 2005.

[24]Nor'Aini Yusof, Siti Nur Fadzilah Mohd Fauzi, Nazirah Zainul Abidin, Hanizan Awang,"Improving graduates' employability skills through industrial training: suggestion from employers", journal of education and practice, vol.4, no. $4,2013$.

[25]Lattuca, R.Lisa, T.Patrick, J.Terenzini, Fredricks Volkwein, "Engineering Change: A Study of the Impact of EC2000", Center for the Study of Higher Education, The Pennsylvania State University, ABET, inc., Maryland, USA,2006. 
[26]N.Spinks,N.Silburn,D.Birchall,"Educating engineers for the 21 st century : The industry view",The royal academy of engineering, London, 2006.

[27]"Educating engineers for the 21st century: The industry view", Henley Management College for Royal Academy of Engineering, 2006.

[28]C.Ferguson, Defining the Australian mechanical engineer, European journal of engineering education, vol.31,pp.471-485, 2006.

[29]J.E. Mills, "The effectiveness of project-based learning in structural engineering", Curtin university of technology, perth,2002.

[30]W.Ravesteijn, E.D.Graaff, O.Kroesen, "Engineering the future: the social necessity of communicative engineers", European journal of engineering education, vol.31, pp.63-71,2006.

[31]National academy of engineering,"The engineer of 2020: Visions of engineering in the new century",Washinghton ,DC:National Academic press, 2004.

[32]P.J.Ashman, S.Scrutton, D. Stringer, P.J.Mullinger, and J.Willison, "Stakeholder perceptions of chemical engineering graduate attributes at the University of Adelaide", Chemeca 2008: Towards a Sustainable Australasia,2008.

[33]W.Bons, A.McLay,'"Re-engineering Engineering Curricula for Tomorrow's Engineers", In Engineering Education for a Sustainable Future: Proceedings of the 14th Annual Conference for Australasian Association for Engineering Education and 9th Australasian Women in Engineering Forum, Australasian Association for Engineering Education,pp.65,2003.

[34]C.S.Nair, A.Patil, P.Mertova,"Re-engineering graduate skills- a case study. European journal of engineering education", vol.34, pp.131 - 139, 2009.

[35]World Chemical Engineering Council, How does chemical engineering education meet the requirements of employment? Frankfurt: World Chemical Engineering Council, 2004.

[36]Sukhwinder Singh Jolly, "Developing soft skills for enhancing employability of engineering graduates", International journal of engineering and management research, vol.2, pp.54-56, 2012.
[37]G.Scott, K.W.Yates, “Using successful graduates to improve the quality of undergraduate engineering programmes", European journal of engineering education, vol.27, pp.363 - 378, 2002.

[38]M.Y.Yuzainee, M.Z.Omar, A.Zaharim, "Employability skills for an entry level engineer as seen by Malaysian employers", IEEE Global engineering education conference (EDUCON) learning environments' and ecosystems in engineering education, 2011.

[39]M. S. Rao, "Soft skills enhancing employability: Connecting campus with corporate", New DelhiInternational Publishing House, 2010.

[ 40 ] G. L o ck, K. B ullock, V. Gould, M.Hermadi,"'Exploring the industrial placement experience for mechanical engineering undergraduate", Engineering education, vol.4, 2009.

[41]L.Harvey, W.Locke and A.Morey,'Enhancing Employability Recognising Diversity", London, Universities UK, 2002.

[42]S.A.Male, Bush, K.Murray,'Think engineer, Think Male? European journal of engineering education", vol.34, pp.455-464, 2009.

43]M.E.Derro and C.R.Williams, "Behavioral competencies of highly regarded systems engineers at NASA", Proceedings of Aerospace Conference, Los Alamitos, CA: IEEE Publications, pp. 1-17, 2009.

[44]Lee Fui Tong, "Identifying essential learning skills in students", Engineering education, Monash University Malaysia, 2003.

45]R.Martin, B.Maytham, J.Case,"Engineering graduates' perceptions of how well they were prepared for work in industry", European journal of engineering education, vol.30, pp.167-180, 2005.

[46]National board of accreditation, Evaluation guidelines for NBA accreditation of undergraduate engineering programme. National board of accreditation, New Delhi, India, 2009.

47]NBA, National Board of Accreditation, Manual for Accreditation of Under Graduate Engineering Programs, 1st Edition, March 2012.

[48]www.abet.org/

[49]www.naac.gov.in 